\title{
A new species of Casmaria H. Adams \& A. Adams, 1853 (Gastropoda, Cassidae) from the Philippines identified by molecular data
}

\author{
Alexander FEDOSOV ${ }^{1,4, *}$, Baldomero M. OLIVERA ${ }^{2,5}$, Maren WATKINS ${ }^{2,6}$ \\ \& Varvara BARKALOVA ${ }^{3,7}$
}

\author{
${ }^{1}$ A.N. Severtsov Institute of Ecology and Evolution, Russian Academy of Sciences, \\ 119071, Leninsky prospect 33, Moscow, Russia \\ ${ }^{2}$ Department of Biology, University of Utah, Salt Lake City, UT 84112, USA \\ ${ }^{3}$ Moscow State University, Faculty of Biology, 1-12, Leninskie Gory, Moscow, 119991 Russia \\ ${ }^{*}$ Corresponding author e-mail: fedosovalexander@gmail.com \\ ${ }^{4}$ urn:1sid:zoobank.org:author:65A25D60-A36D-48E5-9A03-B21207A0FAE2 \\ ${ }^{5}$ urn:1sid:zoobank.org:author:6378C0BB-05EF-4772-9CB9-0DD10BD9233E \\ ${ }^{6}$ urn:1sid:zoobank.org:author:D8C297B4-2A7F-4E60-9295-A22E2EE60581 \\ ${ }^{7}$ urn:1sid:zoobank.org:author:96884FF5-5586-47B3-AE82-B0BC9E74DD76
}

\begin{abstract}
The genus Casmaria H. Adams \& A. Adams, 1853 (family Cassidae) is widespread in the tropical Indo-Pacific and has been documented from some Atlantic localities as well. Two Casmaria species, C. erinaceus (Linnaeus, 1758) and C. ponderosa (Gmelin, 1791), are common in Indo-Pacific shallow-water sandy bottom communities and are characterized by high morphological variability; both species encompass multiple, often sympatric forms of uncertain status. In the present study we carry out a phylogenetic analysis of some Philippine Casmaria morphs and demonstrate that one of the distinctive morphs earlier assigned to Casmaria ponderosa is in fact a different species, which we describe as Casmaria boblehmani sp. nov. The smooth form of Casmaria ponderosa, C. ponderosa ponderosa, and the solid nodulose form, widely called "form nodulosa" despite being strikingly different in shell morphology, are shown to be conspecific. Studied specimens of these two morphs even from different localities share the same haplotype of the $\mathrm{CO} 1$ gene. In light of these new data on the morphological variability of Casmaria species, we discuss criteria of species delimitation in the genus Casmaria and possible affinities of Casmaria boblehmani sp. nov. within the genus.
\end{abstract}

Keywords. Polymorphic species, CO1, Cassidae, Casmaria, Indo-Pacific.

Fedosov A., Olivera B.M., Watkins M. \& Barkalova V. 2014, A new species of Casmaria H. Adams \& A. Adams, 1853 (Gastropoda, Cassidae) from the Philippines identified by molecular data. European Journal of Taxonomy 78: 1-13. http://dx.doi.org/10.5852/ejt.2014.78

\section{Introduction}

The genus Casmaria H. Adams \& A. Adams, 1853, or bonnet shells, is a distinctive group of the family Cassidae, easily recognizable by a set of shell characters, among which are a closed umbilicus and 
the complete lack of shell sculpture in many species. The genus is widely distributed in shallow-water marine communities of the tropical zone. Its members are abundant on sandy bottoms of the Indo-Pacific from Madagascar to Hawaii and eastern French Polynesia, and are also known from some Atlantic localities, mainly in the Caribbean province (Clench 1944; Abbott 1968).

Despite the fact that the number of species and subspecies currently attributed to the genus Casmaria hardly exceeds a dozen (Kreipl 1997; Buijse et al. 2013; WoRMS (www.marinespecies.org, accessed 10 Feb 2014)), the taxonomy of the genus remains problematic. Traditionally, diverse Indo-Pacific Casmaria forms were lumped into two polymorphic and extremely widespread species, C. erinaceus (Linnaeus, 1758) and C. ponderosa (Gmelin, 1791), consistent with the general wide perception of species in the group established by Abbott (1968). In these two species a number of morphologically distinct forms were named that occur in restricted localities, mostly from the periphery of Indo-Pacific; recently, most of these were given the status of full species (Buijse et al. 2013).

In the central Indo-Pacific both Casmaria erinaceus and C. ponderosa are represented by several sympatric forms, some of them strikingly different in appearance. Firstly, each of the two Casmaria species encompasses a smooth, usually thin-shelled form (C. erinaceus vibex and $C$. ponderosa ponderosa) and a more robust form, bearing nodules around the periphery (C. erinaceus erinaceus and C. ponderosa nodulosa) (Kreipl 2008; Beu et al. 2012). Moreover, specimens of both C. erinaceus and C. ponderosa demonstrate significant variation in color pattern. The status of these sympatric forms of C. erinaceus and C. ponderosa is uncertain, and the conspecificity of the smooth and nodulose forms in both species remains unproven.

In the present study we carry out a molecular-phylogenetic analysis of a set of sympatric Casmaria forms from the central Indo-Pacific, mainly from the Central Philippines, in order to establish species limits in Indo-Pacific Casmaria species.

\section{Material and methods}

\section{Material}

Material for molecular studies was collected by night diving in mid-June 2012 at Danajon Banks, off Olango Island, Cebu Province, in the Central Philippines (seven specimens) and in September 2012 at Murray Beach, off Mun Island, Nha Trang Bay, Vietnam (three specimens). Using conventional taxonomy, nine of the specimens were initially assigned to Casmaria ponderosa and one specimen to Casmaria erinaceus. The nine specimens of Casmaria ponderosa represented both the smooth form, known as C. ponderosa ponderosa, and a solid morphotype widely identified as " $C$. ponderosa nodulosa". They also demonstrated a considerable variation in color pattern.

In the field a fragment of foot tissue was clipped from each specimen and preserved in $99 \%$ ethanol for subsequent DNA extraction.

\section{Preparation of genomic DNA and amplification of selected genetic markers}

Genomic DNA was extracted from foot tissue samples using the Gentra PUREGENE DNA Isolation Kit (Gentra Systems, Minneapolis, MN) according to the manufacturer's standard protocol. The 12S, 16S and $\mathrm{CO} 1$ fragments were amplified using genomic DNA as a template for polymerase chain reaction (for details of the PCR reactions, see Fedosov et al. (2011)). The resulting PCR products were purified by gel electrophoresis and the DNA fragments recovered from agarose. 
Table 1. Summary of specimens used for molecular analysis.

\begin{tabular}{|c|c|c|c|c|c|c|c|}
\hline Species & Isolate & BOLD ID & $\begin{array}{c}\text { Museum } \\
\text { catalogue number }\end{array}$ & $\begin{array}{c}\mathrm{CO} 1 \\
\text { GenBank } \\
\end{array}$ & $\begin{array}{c}16 \mathrm{~S} \\
\text { GenBank }\end{array}$ & $\begin{array}{c}12 \mathrm{~S} \\
\text { GenBank } \\
\end{array}$ & Locality data \\
\hline C. erinaceus & Casm.1 & & & KC505344 & KC505353 & KC505363 & $\begin{array}{l}\text { Philippines, off Olango Is, Denajon Bank, } \\
10^{\circ} 17.8^{\prime} \mathrm{N} 124^{\circ} 05.3^{\prime} \mathrm{E}, 15-25 \mathrm{~m}\end{array}$ \\
\hline C. erinaceus & IM-2007-33621 & TONO119-13 & $\begin{array}{c}\text { MNHN } \\
\text { IM-2007-33621 }\end{array}$ & KC970029 & & & $\begin{array}{l}\text { Philippines, Panglao Is, PANGLAO } 2004 \\
\text { Stn. R3, 9³3.0'N } 123^{\circ} 46.5^{\circ} \mathrm{E}, 5-24 \mathrm{~m}\end{array}$ \\
\hline C. ponderosa & Casm.2 & & & KC505343 & KC505352 & KC505362 & $\begin{array}{l}\text { Philippines, off Olango Is, Denajon Bank, } \\
10^{\circ} 17.8^{\prime} \mathrm{N} 124^{\circ} 05.3^{\prime} \mathrm{E}, 15-25 \mathrm{~m}\end{array}$ \\
\hline C. ponderosa & Casm.3 & & & KC505342 & KC505351 & KC505361 & $\begin{array}{l}\text { Philippines, off Olango Is, Denajon Bank, } \\
10^{\circ} 17.8^{\prime} \mathrm{N} 124^{\circ} 05.3^{\prime} \mathrm{E}, 15-25 \mathrm{~m}\end{array}$ \\
\hline C. ponderosa & Casm.4 & & & KC505341 & KC505350 & KC505360 & $\begin{array}{l}\text { Philippines, off Olango Is, Denajon Bank, } \\
10^{\circ} 17.8^{\prime} \mathrm{N} 124^{\circ} 05.3^{\prime} \mathrm{E}, 15-25 \mathrm{~m}\end{array}$ \\
\hline C. ponderosa & Casm. 8 & & & KC505340 & KC505349 & KC505359 & $\begin{array}{l}\text { Philippines, off Olango Is, Denajon Bank, } \\
10^{\circ} 17.8^{\prime} \mathrm{N} 124^{\circ} 05.3^{\prime} \mathrm{E}, 15-25 \mathrm{~m}\end{array}$ \\
\hline C. ponderosa & Casm.V1 & & & KC505339 & KC505348 & KC505358 & $\begin{array}{l}\text { Vietnam, Nha-Trang Bay, off Mun Is, } \\
12^{\circ} 10.084^{\prime} \mathrm{N}, 109^{\circ} 17.771^{\prime} \mathrm{E}, 6-12 \mathrm{~m}\end{array}$ \\
\hline C. ponderosa & Casm.V2 & & & KC505338 & KC505347 & KC505357 & $\begin{array}{l}\text { Vietnam, Nha-Trang Bay, off Mun Is, } \\
12^{\circ} 10.084^{\prime} \mathrm{N}, 109^{\circ} 17.771^{\prime} \mathrm{E}, 6-12 \mathrm{~m}\end{array}$ \\
\hline C. ponderosa & Casm.V3 & & & KC505337 & KC505346 & KC505356 & $\begin{array}{l}\text { Vietnam, Nha-Trang Bay, off Mun Is, } \\
12^{\circ} 10.084^{\prime} \mathrm{N}, 109^{\circ} 17.771^{\prime} \mathrm{E}, 6-12 \mathrm{~m}\end{array}$ \\
\hline C. boblehmani sp. nov. & Casm. 5 & & $\begin{array}{c}\text { Holotype } \\
\text { ANSP } 453749\end{array}$ & KC505336 & KC505355 & KC505365 & $\begin{array}{l}\text { Philippines, off Olango Is, Denajon Bank, } \\
10^{\circ} 17.8^{\prime} \mathrm{N} 124^{\circ} 05.3^{\prime} \mathrm{E}, 15-25 \mathrm{~m}\end{array}$ \\
\hline C. boblehmani sp. nov. & Casm.7 & & $\begin{array}{c}\text { Paratype } 2 \\
\text { ANSP } 453750\end{array}$ & KC505345 & KC505354 & KC505364 & $\begin{array}{l}\text { Philippines, off Olango Is, Denajon Bank, } \\
10^{\circ} 17.8^{\prime} \mathrm{N} 124^{\circ} 05.3^{\prime} \mathrm{E}, 15-25 \mathrm{~m}\end{array}$ \\
\hline C. boblehmani sp. nov. & IM-2007-33625 & TONO121-13 & $\begin{array}{c}\text { MNHN } \\
\text { IM-2007-33625 }\end{array}$ & KC970027 & & & $\begin{array}{l}\text { Vanuatu, SANTO } 2006 \text { Stn. FR10, } \\
15^{\circ} 36.7^{\prime} \mathrm{S} 167^{\circ} 05.8^{\prime} \mathrm{E}, 5-25 \mathrm{~m}\end{array}$ \\
\hline C. boblehmani sp. nov. & IM-2007-33628 & TONO120-13 & $\begin{array}{c}\text { MNHN } \\
\text { IM-2007-33628 }\end{array}$ & KC970028 & & & $\begin{array}{l}\text { Vanuatu, SANTO } 2006 \text { Stn. FR03, } \\
15^{\circ} 36.2^{\prime} \mathrm{S} 167^{\circ} 06.3^{\prime} \mathrm{E}, 3-32 \mathrm{~m}\end{array}$ \\
\hline \multicolumn{8}{|l|}{ OUTGROUPS } \\
\hline Distorsio reticularis & & & & HQ834113 & HQ833981 & HQ833859 & \\
\hline Linatella caudata & & & & JF693368 & HQ833982 & HQ833860 & \\
\hline Erronea errones & & & & HQ834112 & HQ833980 & HQ833858 & \\
\hline Semicassis pyrum & & & & AF550508 & & & \\
\hline
\end{tabular}




\section{Characterization of clones encoding $12 S, 16 \mathrm{~S}$ and CO1 sequences}

The purified DNA fragments were annealed to the pNEB206A vector using the USER Friendly Cloning kit (New England BioLabs, Inc., Beverly, MA) following the manufacturer's suggested protocol, and the resulting product transformed into competent cells. The nucleic acid sequences of the resulting $12 \mathrm{~S}, 16 \mathrm{~S}$ and CO1-encoding clones were determined according to the standard protocol for automated sequencing at the Health Sciences Center Core Sequencing Facility, University of Utah. Sequences of six individual $12 \mathrm{~S}, 16 \mathrm{~S}$ and $\mathrm{CO} 1$-encoding clones from each specimen were compared to ensure sequence consensus.

CO1 sequences of an additional three Casmaria specimens collected during recent expeditions of the Muséum National d'Histoire Naturelle, Paris (MNHN) to the Philippines (PANGLAO 2004 - one specimen) and Vanuatu (SANTO 2006 - two specimens) were contributed by Philippe Bouchet and Nicolas Puillandre (MNHN). For sequence GenBank accession numbers and detailed locality data see Table 1.

\section{Phylogenetic analysis}

CO1, 12S and 16S sequences of three caenogastropod species, Distorsio reticularis (Linnaeus, 1758) (Tonnoidea: Personidae), Linatella caudata (Gmelin, 1791) (Tonnoidea: Ranellidae) and Erronea errones (Linnaeus, 1758) (Cypraeidae), accessed in GenBank were used as outgroups. Semicassis pyrum (Lamarck, 1822) (Cassidae) was used as a within family outgroup in CO1 analysis. Sequences were aligned for each gene independently using MUSCLE (Edgar 2004). The accuracy of automatic alignments was then confirmed by eye using BioEdit version 7.0.0.0 (Hall 1999). Hypervariable regions of the $12 \mathrm{~S}$ and $16 \mathrm{~S}$ rRNA genes were excluded from further analyses. Parameters of the substitution model were estimated during the analysis (six substitution categories, a gamma-distributed rate variation across sites approximated in four discrete categories and a proportion of invariable sites) independently for each codon position of the $\mathrm{CO} 1$ gene. Bayesian Analysis was performed in two parallel runs in MrBayes (Huelsenbeck et al. 2001), each consisting of six Markov chains of 10,000,000 generations with a sampling frequency of one tree each 10,000 generations and with the chain temperature set to 0.02 . When log-likelihood scores were found to stabilize, consensus trees were calculated after omitting the first $25 \%$ of trees as burn in.

Abbreviations used in text

ANSP = Academy of Natural Sciences, Philadelphia, USA

MNHN = Muséum National d'Histoire Naturelle, Paris, France

\section{Results}

\section{Phylogenetic analysis}

Phylogenetic trees constructed after analysis of three molecular markers (Fig. 1 A-C) are congruent and are characterized by high support of terminal groupings (PP values indicated in bold). The monophyly of Casmaria is supported in analyses of all three markers, although this result requires further confirmation after the analysis of a more representative dataset. In all three single-gene trees the studied specimens of the genus Casmaria form three distinct groups; the within-group K2P genetic distance computed for the $\mathrm{CO} 1$ gene averaged $0.53 \%$, and was always lower than the minimal between-group K2P genetic distance $(6.3 \%)$. This difference corresponds to the so-called "barcode gap" and suggests a specific status for each of the groups (Puillandre et al. 2012).

The first grouping, represented by two specimens on the CO1-based tree and a single specimen on the $12 \mathrm{~S}$ and $16 \mathrm{~S}$ trees, corresponds to Casmaria erinaceus. Specimens preliminarily identified as Casmaria ponderosa formed two separate, well-supported clades on the phylogenetic trees. One of these clades, including four smooth Philippine specimens and three nodulose specimens from Vietnam, corresponds to 
FEDOSOV A. et al., New species of Casmaria from the Philippines

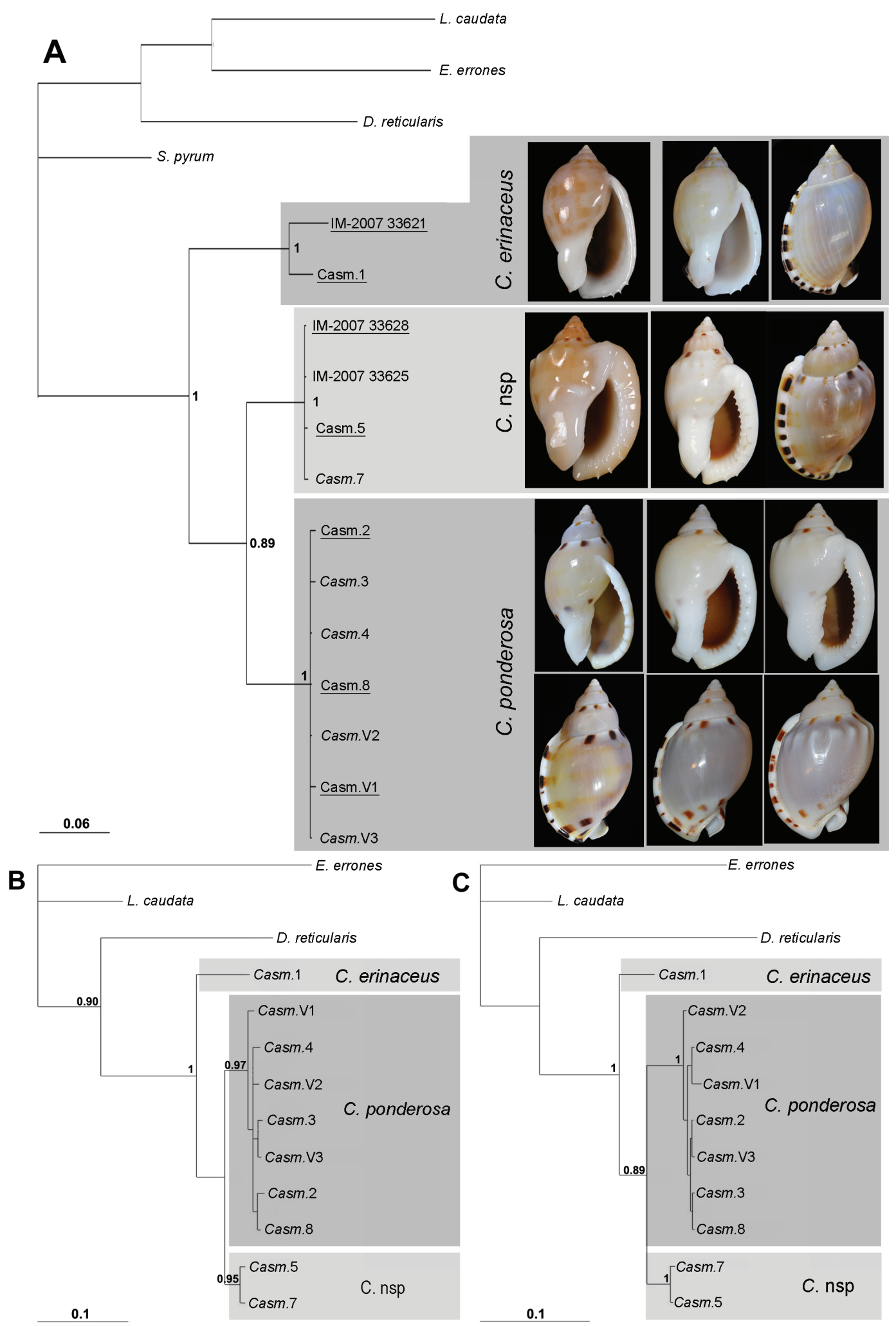

Fig. 1. Bayesian phylogenetic trees of studied members of the genus Casmaria obtained with standard genetic markers. Posterior probabilities when greater than 0.80 are indicated for each node. A. Phylogenetic tree based on the $\mathrm{CO} 1$ gene; for specimens underlined, vouchers are illustrated on the right. B. Phylogenetic tree based on the 16S rRNA gene. C. Phylogenetic tree based on the 12S rRNA gene. 
Casmaria ponderosa. Smooth specimens represent the typical form, Casmaria ponderosa ponderosa and correspond to the type material of this species (Buijse et al. 2013). It is noteworthy that four specimens of this grouping, two smooth Philippine specimens (Casm.4, Casm.8) and two nodulose Vietnamese specimens (Casm.V2, Casm.V3), had identical CO1 sequences. The four specimens forming the second clade, two nodulose Philippine specimens and two additional specimens from Vanuatu on the CO1-based tree, represent a distinct morphotype, morphologically similar to so-called C. ponderosa nodulosa, but differing in details of shell structure and coloration (see below), which were previously widely attributed to Casmaria ponderosa. Our results recognize this morphotype as an undoubted distinct species separate from both C. erinaceus and C. ponderosa; its description is given below.

Taxonomic account

Family Cassidae Latreille, 1825

Subfamily Phaliinae Beu, 1981

Genus Casmaria H. Adams \& A. Adams, 1853

\section{Type species}

Buccinum vibex Linnaeus, 1758 (= Casmaria erinaceus (Linnaeus, 1758)) (by subsequent designation in Harris 1897)

\section{Note on the synonymy and relevant types of Casmaria ponderosa}

Casmaria ponderosa has a long and complex synonymy, which has recently been comprehensively analyzed by Beu et al. (2012). All relevant type specimens were tracked down or proven to be lost. The syntype of Cassis torquata Reeve, 1848, illustrated earlier by Abbott (1968), was designated as the lectotype and also as the neotype of Buccinum ponderosum Gmelin, 1791, B. nodulosum Gmelin, 1791, Phalium quadratum Link, 1807, Buccinum biarmatum Dillwyn, 1817, Buccinum pantherina Dillwyn, 1817, and Cassis tenuilabris Menke, 1828 (Beu et al. 2012: 78). For this reason, none of these names can apply to the new species we describe.

Casmaria boblehmani sp. nov.

urn:1sid:zoobank.org:act:FA0142B4-BEF4-4F08-8BFD-C0870F39DC88

Fig. 2

Casmaria ponderosa - Robin 2008: 145, fig. 5 - Buijse et al. 2013: 13, fig. 25-2 [middle specimen], pl. 6, figs $6,8,13$, pl. 7, figs $1,5,8-10,12-15,17$, pl. 8, fig. 1, ?pl. 10, fig. 11.

\section{Etymology}

This species is named to honor I. Robert (Bob) Lehman, a great scientist, mentor and teacher. One of the authors $(\mathrm{BMO})$ has been the grateful direct beneficiary of his remarkable generosity.

\section{Type material}

\section{Holotype}

Molecular voucher Casm.5, 36.3 mm, Danajon Banks, off Olango Island, Cebu, Philippines, $10^{\circ} 17.8^{\prime} \mathrm{N}$, $124^{\circ} 05.3^{\prime}$ E, 10-25 m, coll. local diver, Jun. 2012, ANSP-453749 (Fig. 2A-C).

\section{Paratypes}

$1(35.1 \mathrm{~mm})$ and $2(34.8 \mathrm{~mm}$, molecular voucher Casm. 7), same locality as holotype, ANSP-453750 (Fig. 2D-E). The holotype and paratype 2 provided the two DNA sequences labeled Casm. 7 and Casm. 5, respectively, in Fig. 1. 


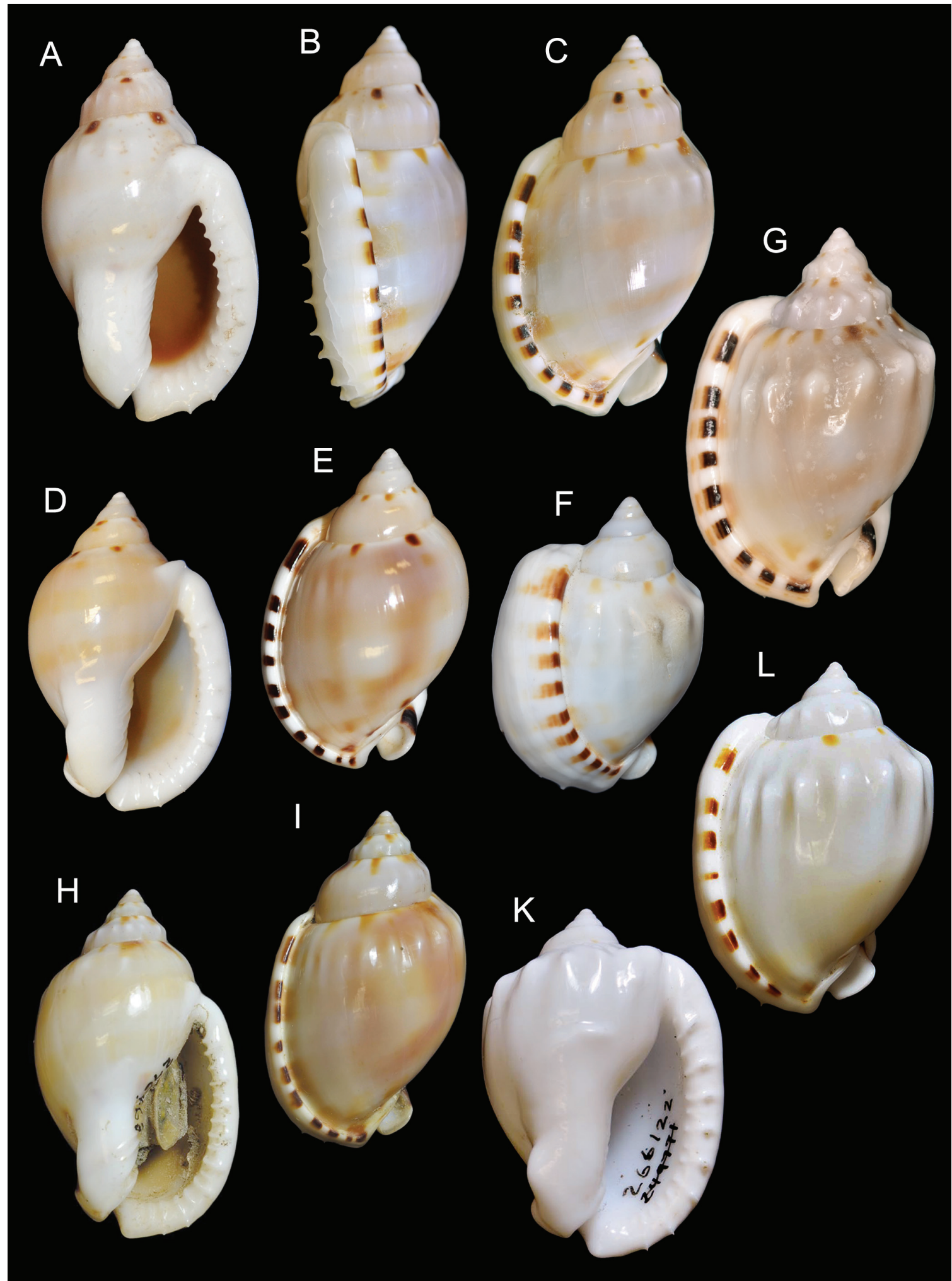

Fig. 2. Casmaria boblehmani sp. nov. A-C. Holotype, 36.3 x $19.5 \mathrm{~mm}$, Danajon Banks, Olango Is, Philippines. D-E. Paratype 2, 35.1 x $21.7 \mathrm{~mm}$, same locality as holotype. F. 27.7 x $18.8 \mathrm{~mm}$, Tip of Cape York, Queensland, Australia. G. 38.6 x 25.4 mm, off Woka Island, Molucca Sea, Indonesia. H-I. ANSP 276463, 41.5 x 24.2 mm, Akuilan Is, Fiji. K-L. ANSP 266122, 36.5 x 24.6 mm, Atiue, Tahiti, Society Islands. 


\section{Other material examined}

PHILIPPINES: $34.6 \mathrm{~mm}$, off Masbate Island, Central Philippines, coll. local diver, BO collection; 34.9 $\mathrm{mm}$, off Calituban Island, Bohol, $9 \mathrm{~m}$, on mud, BO collection; $44.9 \mathrm{~mm}$, off Cuyo Island, Palawan, 10-25 $\mathrm{m}$, BO collection; $32.2 \mathrm{~mm}$, Palawan Island, unknown locality, $10-15 \mathrm{~m}$, BO collection. AUSTRALIA: $27.7 \times 18.8 \mathrm{~mm}$, tip of Cape Yorke, Queensland, BO collection (Fig. 2F). INDONESIA: 38.6 x $25.4 \mathrm{~mm}$, off Woka Island, Molucca Sea, BO collection (Fig. 2G). VANUATU: juv., Expedition "SANTO 2006", Stn. FR10, Belmoul Lagoon, $15^{\circ} 36.7^{\prime}$ S, $1^{\circ} 7^{\circ} 05.8^{\prime}$ E, 5-25 m, MNHN IM-2007-33625; juv., Expedition “SANTO 2006", Stn. FR03, Belmoul Lagoon entrance, $1^{\circ} 36.2^{\prime}$ S, 16706.3' E, 3-32 m, MNHN IM2007-33628 (Fig. 1A). FIJI: 41.5 x 24.2 mm, off Akuilan Island, ANSP 276463 (Fig. 2H-I). SOCIETY ISLANDS: 36.5 × 24.6 mm, Atiue, Tahiti, ANSP 266122 (Fig. 2K-L).

\section{Description}

Adult shell small to medium-sized, solid, glossy, ovate-elongate with very prominent terminal varix, studied specimens $34.8-36.3 \mathrm{~mm}$ high. Proportions of shell vary considerably, ratio of shell breadth to height $0.58-0.7$. Protoconch of about 4 smooth, evenly convex whorls. Teleoconch of 4-5 whorls; early spire whorls evenly convex, with no sculpture. Last adult whorl and in most specimens penultimate whorl with row of glossy nodules (6 to 12 on last whorl), weakly developed in some specimens (Fig. 2D-E), prominent in others (Fig. 2 G). Due to nodules, late whorls distinctly shouldered; shoulder situated at mid-height of penultimate whorl and adapical quarter of last adult whorl. Aperture ovate, outer lip strongly thickened, drawn upwards, with wide, shallow sinus in upper side. Interior of outer lip with distinct dentition. Apertural varix very prominent, thick, with ten brownish-black blotches on abapertural face; adapertural face with seven or eight well-developed spines directed transversally to apertural plane. Their positions correspond approximately with black blotches on abapertural face. Columellar shield solid, white, heavily callused, with numerous spiral wrinkles in some specimens. Last adult whorl of pinkish, tan, or pale brown background color, with indistinct brown spiral stripes and a row of brown to blackish-brown spots below suture. Siphonal canal with black blotch. Interior of aperture pale brown. Tip of protoconch brown.

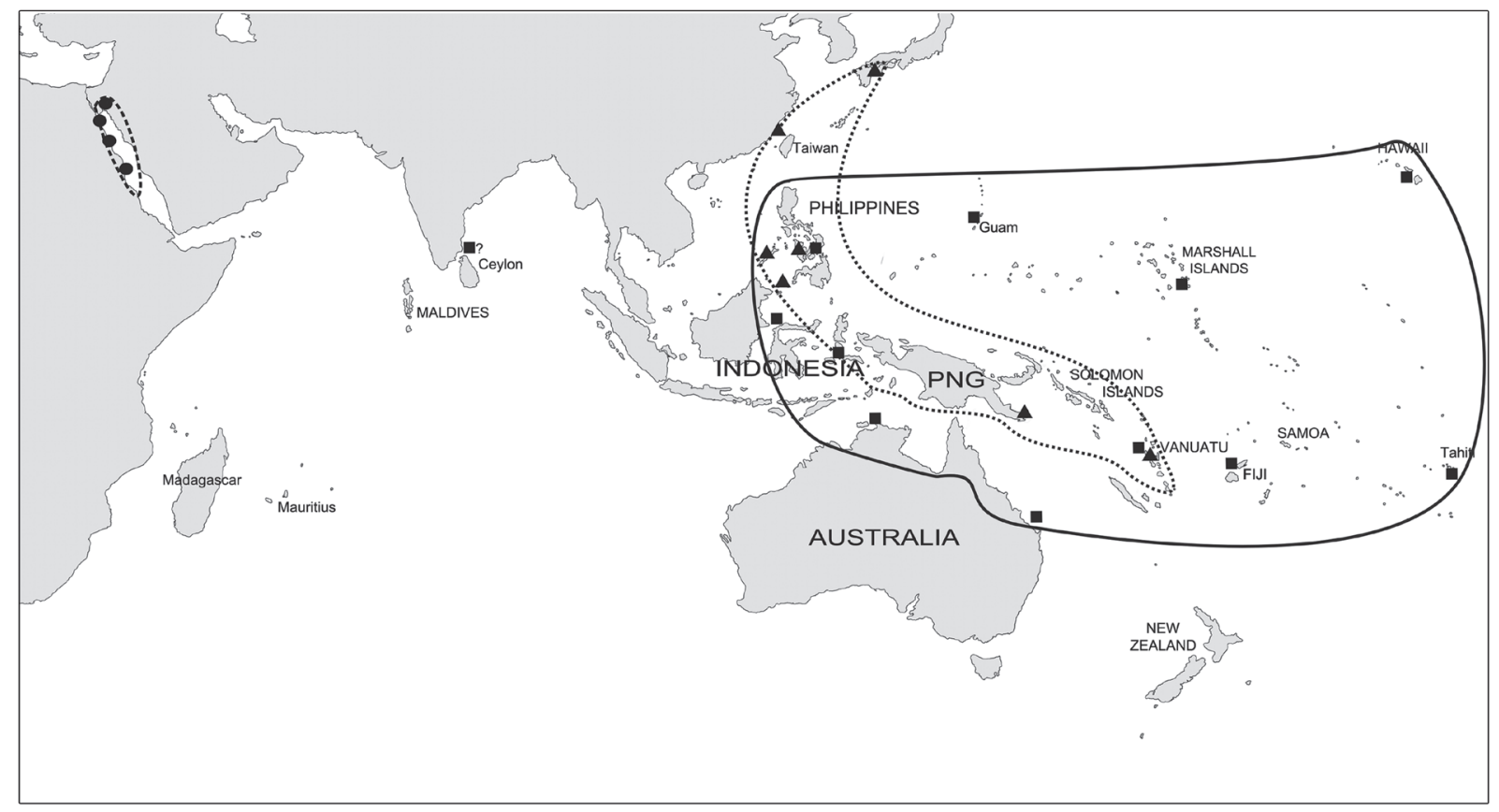

Fig. 3. Distributions of Casmaria turgida (short-dashed line and triangles), C. unicolor (dashed line and filled circles) and C. boblehmani sp. nov. (solid line and squares) in the Indo-Pacific. 


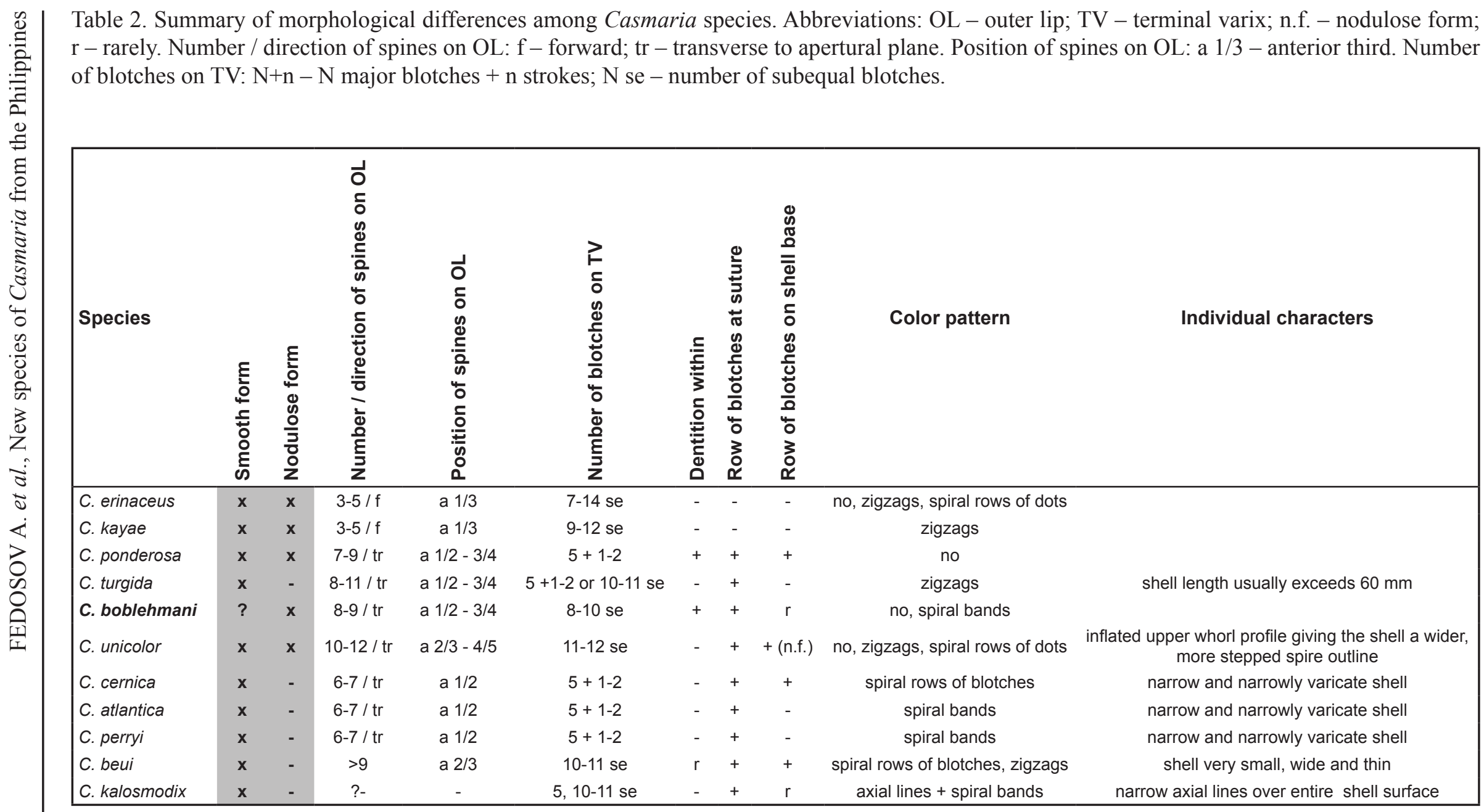




\section{Remarks}

Specimens that are most appropriately assigned to Casmaria boblehmani sp. nov. are found at sites in eastern Indonesia, northern Australia (Northern Territory and Queensland), Vanuatu and the South Pacific. The largest specimen $(51.8 \mathrm{~mm})$ that we can confidently assign to C. boblehmani sp. nov. is known from the Philippines (Buijse et al. 2013: pl. 6, fig. 13). In the Philippines C. boblehmani sp. nov. occurs syntopically with C. ponderosa, C. erinaceus and C. turgida. All four species co-occur in sandy patches at depths of 1 to $30-40$ meters.

Characters allowing the unequivocal recognition of Casmaria boblehmani sp. nov. and the delimitation of the Casmaria species described to date are summarized in Table 2.

Casmaria ponderosa and C. boblehmani sp. nov. can be distinguished from each other by the number and arrangement of brown blotches on the dorsal side (abapertural face) of the terminal varix: C. ponderosa has five major blotches and two to three intermediate strokes, while $C$. boblehmani sp. nov. has nine to ten blotches of equal or subequal size, evenly distributed along the varix of most specimens. Another character, although less stable, is a row of spots on the shell base, posterior to the siphonal canal. These are always distinct in C. ponderosa, but are missing in most specimens, or in rare cases present but indistinct, in C. boblehmani sp. nov.

Specimens of Casmaria erinaceus can easily be distinguished from both C. ponderosa and C. boblehmani sp. nov. by the absence of dentition on the inner surface of the outer lip and by the presence of only three or four (very rarely five) spines restricted to the anterior edge of the outer lip, directed forward. The anterior edge of the outer lip is drawn slightly forward and abaxially. Both C. ponderosa and $C$. boblehmani sp. nov. have distinct dentition on the inner surface of the outer lip and have six or more spines directed transversely to the apertural plane, located along the anterior and medial edges of the outer lip. Most of these characters were mentioned by Abbott (1968) and Buijse et al. (2013) as allowing discrimination between C. erinaceus and C. ponderosa.

Casmaria boblehmani sp. nov. can be readily distinguished from Casmaria turgida (Reeve, 1848). The latter species is rather conservative in morphology throughout its range (Buijse et al. 2013) and has a shell with evenly convex whorls, notable because of the characteristic zigzag color pattern. Besides that, C. turgida exceeds all co-occurring Casmaria forms in size. Unfortunately, C. turgida is missing in our molecular dataset. However, the conservative morphology of this species and its sympatry on a small scale with $C$. erinaceus, $C$. ponderosa and $C$. boblehmani sp. nov. at a number of Indo-Pacific localities prove that it is a distinct species.

Despite the fact that C. ponderosa, C. boblehmani and C. turgida in most cases can be distinguished from each other confidently by the combination of characters discussed above, these characters may intergrade to a certain extent, creating somewhat intermediate forms that may be difficult to interpret. Buijse et al. (2013: pl. 6, figs 6, 8, pl. 9, fig. 15) depicted a few specimens of intermediate appearance that we are not certain where to assign. All these specimens have smooth shells intermediate between $C$. ponderosa and C. turgida in size (48-51 mm).

Among the other Casmaria species not occurring sympatrically with $C$. boblehmani sp. nov., $C$. unicolor (Pallary, 1926) is probably the most similar. As in other Casmaria species, C. unicolor varies significantly in sculpture and encompasses both smooth and nodulose forms, and the nodulose form closely resembles C. boblehmani sp. nov. (see Buijse et al. 2013: pl. 22). These two forms seem to differ in the number of spines on the outer lip. C. boblehmani sp. nov. possesses seven to eight spines, while $C$. unicolor has 10-12, and they are located along the entire length of the lip in many specimens, reaching the adapical angle of the aperture. Apart from that, C. unicolor can be distinguished by its more inflated 
upper (adapical) whorl profile and more clearly distinguished, weakly flattened sutural ramp, giving it a wider, more stepped spire outline. Casmaria unicolor is restricted to the Red Sea (Fig. 3), and the widely distant distributions of this species and C. boblehmani sp. nov. suggest that these two forms are sufficiently divergent to be considered as separate species.

The three species Casmaria cernica (G. B. Sowerby III, 1888), C. perryi (Iredale, 1912) and C. atlantica Clench, 1944 are extremely similar to each other. They are characterized by being narrower in outline and with a narrower terminal varix than C. boblehmani sp. nov. Besides that, all three mentioned species share the same arrangement of dark blotches on the dorsal side of the apertural varix as in C. ponderosa: five major blotches with one or two intermediate strokes between each major pair.

In comparison with Casmaria boblehmani sp. nov., C. kalosmodix (Melvill, 1883) has a much larger, far more elongate and more narrowly varicate shell with narrow axial color lines that are not present in other Casmaria species, and with no spines on the outer lip. As in C. boblehmani sp. nov., the blotches on the abapertural face of the varix in C. kalosmodix are narrow, but in the latter species they are grouped in 3-4 clusters, separated by wide interspaces.

Another species, Casmaria kayae Buijse, Dekker \& Verbinnen, 2013, in general resembles C. erinaceus. C. boblehmani sp. nov. can easily be distinguished from C. kayae by the number and position of spines on the outer lip and by the color pattern. C. kayae has three or four (five in a few specimens) spines on the anterior portion of the lip, and these are directed forward. Many specimens have a distinctive zigzag color pattern, quite different from the usual coloration of C. boblehmani sp. nov.

Finally, C. beui Buijse, Dekker \& Verbinnen, 2013, from Western Indian Ocean, can easily be distinguished from C. boblehmani sp. nov. by its small size, its smooth, thin, relatively very wide shell with distinctively inflated whorls, and by its characteristic color pattern, resembling that of C. turgida.

\section{Distribution}

Casmaria boblehmani sp. nov. is widely distributed across the Pacific Ocean: from the Philippines, eastern Indonesia, northern Australia, to Fiji and the Society Islands, and (based on specimens illustrated by Buijse et al. 2013) to Hawaii (Fig. 3). Possibly reaches India (based on the specimen illustrated by Robin 2008).

\section{Discussion}

Traditionally, characters of shell shape and sculpture are given more taxonomic weight than coloration, especially in groups with highly variable shells. In particular, in the genus Casmaria the presence or absence of nodules on the shoulder dramatically changes the appearance of the shell; ever since the original description by Linnaeus this has confused the species-level taxonomy of the genus. Our data demonstrate that smooth (typical) and nodulose specimens of $C$. ponderosa, even from distant localities, may share the same haplotype of the $\mathrm{CO} 1$ gene, suggesting that (1) these forms are conspecific, and therefore (2) the presence or absence of nodules is not a character of taxonomic significance. This is the first evidence independent of traditional conchological data that confirms the conspecificity of distinct morphotypes of one cassid species. The nodulose form of $C$. erinaceus was missing from our dataset, but we expect that it will prove to be conspecific with the smooth form, as with the two forms of $C$. ponderosa. In general, our results support the hypothesis of species delimitation in Cassidae largely based on the assumption that high within-species morphological variability underlies the rise of multiple morphotypes, while these demonstrate no genetic structure.

Identification of a new species morphologically close to Casmaria ponderosa urged us to review the morphology of Indo-Pacific Casmaria species in search of morphological traits that would be consistent 
with our molecular data, allowing the unmistakable delimitation of Indo-Pacific Casmaria species or, at least, of the forms that co-occur in the Philippines. While $C$. erinaceus and $C$. kayae can be easily separated based on the number and arrangement of spines on the outer lip, delimitation of the other species is less straightforward and is largely based on shell proportions and coloration. In particular, the number and arrangement of the dark blotches on the abapertural face of the terminal varix is consistent with our hypothesis of species delimitation in Casmaria and seems to be conservative enough to serve as a good diagnostic character. However, although these characters work well in most cases, they vary from individual to individual and can intergrade, giving rise to rare specimens of an intermediate appearance. Interpretation of these intermediate forms requires further molecular studies.

The morphological characters shown here to be taxonomically significant were largely ignored in prior taxonomic diagnoses of the group, and other overlooked Casmaria species may well exist, distinguishable by more subtle details of shell coloration and morphology and detectable by molecular analysis. Further larger-scale molecular phylogenetic studies on Casmaria and closely related cassid genera are necessary to reveal the hidden diversity of this group.

\section{Acknowledgements}

We are grateful to Philippe Bouchet, Nicolas Puillandre and Barbara Buge (MNHN) for the access to MNHN sequences and their barcode collection, and to Gary Rosenberg and Paul Callomon for loaning specimens from the ANSP collections. We are also grateful to Andreia Salvador (NHMUK), Elaine Charwat (Linnean Society of London) and Igor Muratov (Natal Museum of South Africa) for sending photographs of types in the genus Casmaria. We thank Terry Merritt for assistance in preparation of the manuscript, Patrice Showers Corneli for her review of the manuscript, and Desiree Beaudry and Thong Nguyen for their help in preparation of the figures. We are grateful to Alan Beu, Philippe Bouchet and one anonymous referee for their comments that helped to amend the manuscript, and we thank Alan Beu for his generous help in editing the final text. The specimens were collected on field trips supported in part by International Cooperative Biodiversity Groups (ICBG) grant \#1U01TW008163. This work was partly supported by a grant from the Russian Foundation of Basic Research, RFBR-14-04-31048 (PI A. Fedosov).

\section{References}

Abbott R.T. 1968. The helmet shells of the world (Cassidae). Part 1. Indo-Pacific Mollusca 2 (9): 7-198.

Beu A., Bouchet P. \& Tröndlé J. 2012. Tonnoidean gastropods of French Polynesia. Molluscan research 32: $61-120$.

Buijse J.A., Dekker H. \& Verbinnen G. 2013. On the identity of Casmaria species (Gastropoda, Cassidae), with descriptions of two new species. Acta Conchyliorum 14: 3-93.

Clench W. J. 1944. The genera Casmaria, Galeodea, Phalium and Cassis in the Western Atlantic. Johnsonia 1 (16): 1-16.

Edgar R. C. 2004. MUSCLE: multiple sequence alignment with high accuracy and high throughput. Nucleic Acids Research 32: 1792-1797. http://dx.doi.org/10.1093/nar/gkh340

Fedosov A. E., Watkins M., Showers Corneli P., Heralde F. M. Concepcion G. P. \& Olivera B. M. 2011. Phylogeny of the genus Turris: correlating molecular markers with radular anatomy and shell morphology. Molecular Phylogenetics and Evolution 59: 263-270. http://dx.doi.org/10.1016/j.ympev.2011.01.019

Hall T.A. 1999. BioEdit: a user-friendly biological sequence alignment editor and analysis program for Windows 95/98/NT. Nucleic Acids Symposium Series 41: 95-98. 
Harris G.F. 1897. Catalogue of the Tertiary Mollusca in the Department of Geology, Part I. The Australasian Tertiary Mollusca. British Museum (Natural History), London.

Huelsenbeck J.P., Ronquist F. \& Hall B. 2001. MrBayes: Bayesian inference of phylogenetic trees. Bioinformatics 17: 754-755. http://dx.doi.org/10.1093/bioinformatics/17.8.754

Kreip1 K. 1997. Recent Cassidae. Verlag Christa Hemman, Wiesbaden, Germany.

Kreipl K. 2008. Family Cassidae. In: Poppe G.T. (ed.) Philippine Marine Mollusks. Conchbooks, Hackenheim.

Puillandre N., Lambert A., Brouillet S. \& Achaz G. 2012. ABGD, Automatic Barcode Gap Discovery for primary species delimitation. Molecular Ecology 21 (8): 1864-1877. http://dx.doi.org/10.1111/j.1365294X.2011.05239.X

Robin A. 2008. Encyclopedia of Marine Gastropods. Xenophora and Conchbooks. Hackenheim, Germany.

Manuscript received: 28 October 2013

Manuscript accepted: 3 March 2014

Published on: 28 March 2014

Topic editor: Rudy Jocqué

Desk editor: Kristiaan Hoedemakers

Printed versions of all papers are also deposited in the libraries of the institutes that are members of the EJT consortium: Muséum National d'Histoire Naturelle, Paris, France; National Botanic Garden of Belgium, Meise, Belgium; Royal Museum for Central Africa, Tervuren, Belgium; Natural History Museum, London, United Kingdom; Royal Belgian Institute of Natural Sciences, Brussels, Belgium; Natural History Museum of Denmark, Copenhagen, Denmark. 